\title{
HERMENEUTIKA GADAMERIAN UNTUK MEMAHAMI KUALITAS AUDIT (PEMERIKSAAN KEUANGAN) BPK RI
}

\author{
Ginrey Shandy Algam \\ Universitas Brawijaya \\ ginreyshandy.algam@gmail.com
}

\begin{abstract}
This research aim is to get an understanding of the financial audit quality of BPK RI by interpretative paradigm approach and Gadamer's Hermeneutics as technical data analysis (text). The data (text) has shown that BPK RI still has low financial audit quality whereas people of Indonesia (as stakeholders) have expectation for high financial audit quality. Conversely, BPK RI has claimed for having high financial audit quality. Financial audit quality of BPK RI measured based on compliance of audit practice with the code of ethics and auditing standards. The results showed that the financial audit quality of the BPK RI is not in accordance with the claims, which can be observed from non-compliance with the code of ethics and auditing standards.
\end{abstract}

Keywords:

Audit quality, The Audit Board of The Republic Indonesia, Gadamer's Hermeneutics

Badan Pemeriksa Keuangan Republik Indonesia (BPK RI) dalam siaran persnya yang diunggah pada situs resminya menyatakan bahwa “... opini Wajar Tanpa Pengecualian (WTP) tidak menjamin bahwa pada entitas yang diperiksa tidak ada korupsi, karena pemeriksaan laporan keuangan tidak ditujukan secara khusus untuk mendeteksi adanya korupsi." (BPK RI, 2011). Pernyataan tersebut menunjukkan gejalakegagalan audit, yang terjadi ketika auditor memberikan indikasi kepada publik melalui opininya, bahwa laporan keuangan klien telah disajikan secara wajar sesuai dengan prinsip akuntansi yang diterima umum, padahal faktanya tidak demikian (Pearson, 1987).Terdapat hubungan yang jelas antara kegagalan audit dengan kualitas audit, yang mana kegagalan audit kemungkinan besar terjadi pada audit yang berkualitas rendah (Francis, 2004).Selama tahun 2015, BPK RI telah melakukan pemeriksaan keuangan terhadap 642 laporan keuangan entitas pemerintah dengan rincian:

Tabel 1

Ikhtisar Hasil Pemeriksaan Semester 1 dan 2 Tahun 2015 BPK RI

\begin{tabular}{|c|c|c|c|c|c|c|c|c|c|}
\hline \multirow[t]{3}{*}{ Entitas } & \multirow{3}{*}{$\begin{array}{c}\text { Jumlah Entitas } \\
\text { yang Telah } \\
\text { Diperiksa }\end{array}$} & \multicolumn{8}{|c|}{ Opini BPKRI } \\
\hline & & \multicolumn{2}{|c|}{ WTP } & \multicolumn{2}{|c|}{ WDP } & \multicolumn{2}{|c|}{ TMP } & \multicolumn{2}{|c|}{ TW } \\
\hline & & $\sum$ & $\%$ & $\sum$ & $\%$ & $\sum$ & $\%$ & $\sum$ & $\%$ \\
\hline LKPP & 1 & - & - & 1 & 100 & - & - & - & - \\
\hline LKKL & 96 & 69 & 71,88 & 20 & 20,83 & 7 & 7,29 & - & - \\
\hline LKPD & 539 & 252 & 46,75 & 247 & 45,83 & 35 & 6,49 & 5 & 0,93 \\
\hline LKBL & 6 & 4 & 66,67 & 2 & 33,33 & - & - & - & - \\
\hline TOTAL & 642 & 325 & 50,62 & 270 & 42,06 & 42 & 6,54 & 5 & 0,78 \\
\hline
\end{tabular}

Sumber: Ikhtisar Hasil Pemeriksaan Semester (IHPS) 1 dan 2 Tahun 2015

Dari tabel di atas, dapat dilihat bahwa pada tahun 2015, sebanyak 325 dari 642, atau $50,62 \%$ laporan keuangan entitas pemerintah telah mendapatkan opini WTP. Namun demikian, skor Corruption Perception Index (CPI) Indonesia pada tahun 2015, hanya sebesar 36 dari skor maksimal 100, yang mana semakin tinggi skor CPI menunjukkan bahwa negara tersebut semakin bebas dari korupsi (Transparency International Indonesia, 2016).Skor CPI Indonesia menunjukkan bahwa berdasarkan persepsi pelaku usaha dan pakar korupsi pada sektor publik di Indonesia, masih 
banyak terjadi korupsi yang dilakukan oleh pegawai negeri, penyelenggara negara, dan politisi. Berdasarkan Standar Pemeriksaan Keuangan Negara (SPKN) yang menjadi pedoman BPK RI dalam melakukan pemeriksaan, seharusnya hanya laporan keuangan entitas pemerintah yang telah bebas salah saji material, baik yang disebabkan oleh kecurangan maupun kekeliruan, yang bisa mendapatkan opini WTP. Banyaknya laporan keuangan entitas pemerintah yang mendapatkan opini WTP, seharusnya mengindikasikan bahwa kecurangan atau korupsi pada sektor publik di Indonesia hanya "sedikit" atau jarang terjadi, namun skor CPI Indonesia tidak mengindikasikan kondisi yang sama, sehingga terdapat ketidakselarasan antara kedua hal tersebut.

Beberapa pemberitaan oleh media massa, menunjukkan bahwa meskipun laporan keuangan entitas pemerintah telah mendapatkan opini WTP tetapi masih terjadi korupsi dalam entitas pemerintah tersebut. Di antaranya adalah pada Kementerian Agama tahun 2011 hingga 2013 untuk kasus korupsi Al-Quran (tempo.co, 2014) dan penyelenggaraan ibadah haji (tempo.co, 2015), Kementerian Pemuda dan Olahraga, Kementerian Energi dan Sumber Daya Mineral, Pemerintah Provinsi Riau, Kabupaten Bangkalan, Kabupaten Tegal (detik.com, 2015), dan kemungkinan masih banyak kasus-kasus lain yang tidak diberitakan oleh media massa. Kasus-kasus tersebut dapat dikatakan sebagai kegagalan audit, yang terjadi ketika auditor tidak mampu atau gagal mendeteksi kecurangan sehingga memberikan opini yang salah (Beasley dkk., 2013). Merumuskan opini auditor independen dengan benar, sebenarnya relatif mudah, masalahnya adalah auditor justru menghindari memberikan opini yang seharusnya, sehingga terjadi kesalahan yang biasa disebut dengan gagal audit (Tuanakotta, 2011).

Beasley dkk., (2013) menyatakan bahwa, terdapat empat faktor yang mungkin menjadi penyebab kegagalan auditor dalam mendeteksi kecurangan yang selanjutnya mengakibatkan kegagalan audit antara lain, kegagalan dalam menerapkan due professional care, kurangnya tingkat skeptisisme profesional, ketidakcukupan analisis dalam mengidentifikasi dan menilai risiko, dan kegagalan merespons risiko yang telah teridentifikasi dengan tepat untuk mendapatkan bukti audit yang kompeten dan cukup. Menurut Tuanakotta (2011), pada sektor publik, kemungkinan penyebab kegagalan audit ada dua yaitu, yang bersifat teknis seperti bukti-bukti audit tidak lengkap atau tidak dianalisis dengan benar, dan auditor tidak memiliki kompetensi yang cukup dalam menerapkan professional scepticism dan menggunakan professional judgement, atau yang bersifat non teknis yang berkaitan dengan politik, ancaman baik yang secara implisit atau eksplisit, serta suap menyuap. Pada dasarnya, penyebab-penyebab kegagalan audit tersebut telah diatur secara ketat dalam kode etik dan standar audit, sehingga kegagalan audit menunjukkan adanya ketidakpatuhan terhadap kode etik dan standar audit.

Kegagalan audit memiliki hubungan terbalik dengan kualitas audit, yang mana ketika terjadi kegagalan audit maka dapat disimpulkan bahwa kualitas auditnya rendah, sebaliknya, apabila tidak terjadi kegagalan audit menjadi kualitas auditnya tinggi (Francis, 2004). Tan dan Kao (1999) dalam penelitiannya menyatakan bahwa kualitas kinerja auditor bisa dilihat dari seberapa sering auditor menanggapi dengan benar terhadap setiap audit yang selesai dikerjakan (Mardisar dan Sari, 2007), atau dengan kata lain audit dapat dianggap berkualitas apabila auditor dapat menghindari risiko audit, dan apabila terjadi kegagalan audit, maka hal tersebut menunjukkan bahwa audit tidak berkualitas.

Beberapa definisi kualitas audit yang dikumpulkan dan disarikan oleh Watkins dkk. (2004) dari peneliti lainnya adalah sebagai berikut: 1) Gabungan probabilitas bahwa auditor dapat menemukan pelanggaran dalam sistem akuntansi klien, dan melaporkannya (DeAngelo, 1986); 2) Probabilitas auditor tidak memberikan opini WTP kepada laporan keuangan yang mengandung salah saji material (Lee dkk., 1999); 3) Keakuratan informasi yang dilaporkan oleh auditor (Titman dan Trueman, 1986; Beatty, 1989; Krinsky dan Rotenberg, 1989; Davidson dan Neu, 1993); dan 4) kemampuan audit untuk mengurangi bias dan meningkatkan keakuratan data akuntansi (Wallace, 1980).

Penelitian tentang faktor-faktor yang berpengaruh terhadap kualitas audit telah dilakukan, antara lain, kepatuhan auditor terhadap standar audit (Carcello dkk., 1992), karakteristik auditor 
dan karakteristik auditi (Setyaningrum, 2012), kompetensi auditor (Steckel dkk., 2014; Alim dkk., 2007; Sukriyah dkk., 2009), independensi auditor (Steckel dkk., 2014; Lennox, 1998 dalam Mohamed dan Habib, 2013; Alim dkk., 2007), objektivitas dan pengalaman kerja (Sukriyah dkk., 2009), tekanan anggaran waktu (Manullang, 2010), dan power conflict atau keinginan klien untuk mendapatkan hasil audit yang diinginkan (Deis dan Giroux, 1992), termasuk dengan cara memberikan suap.

Audit dengan kualitas tinggi seharusnya dapat merepresentasikan kemampuan auditor untuk menghasilkan informasi yang meminimisasi perbedaan kondisi ekonomi yang dilaporkan dan kondisi ekonomi yang "benar" (Watkins dkk., 2004). Adanya kasus-kasus yang menunjukkan kegagalan audit BPK RI, mengindikasikan bahwa kualitas audit BPK RI masih rendah. Namun demikian, BPK RI menyatakan bahwa mereka memiliki standar pemeriksaan yang ketat dan melalui proses quality control dan quality assurrance dan menggunakan empat kriteria sesuai dengan Undang-Undang (BPK RI, 2015a). Dari pernyataan tersebut, BPK RI secara tidak langsung mengklaim bahwa auditnya berkualitas tinggi karena telah sesuai dengan SPKN. Berdasarkan uraian latar belakang di atas, maka peneliti tertarik untuk memahami bagaimana kualitas pemeriksaan keuangan BPK RI.

\section{METODE}

Penelitian ini dilakukan dengan menggunakan paradigma interpretif, dan Hermeneutika Gadamerian sebagai teknik analisis data (teks), Berdasarkan pandangan dari Burrel dan Morgan (2005), paradigma interpretif berada pada kuadran "subjective - the sociology of regulation". Paradigma ini memandang realitas sosial sebagai suatu kesatuan yang utuh, namun realitas sosial tersebut lahir dari realitas dari individu-individu. Paradigma ini mencoba memahami dunia dan menjelaskan realitas atas dasar kesadaran individu dan subjektivitas. Sedangkan dalam pandangan Chua (1986), paradigma penelitian ini dikategorikan sebagai the interpretive alternative, yang pada intinya kurang lebih sama dengan paradigma interpretif yang dijelaskan oleh Burrel dan Morgan (2005).

Dalam pandangan paradigma interpretif, status ontologis dari dunia sosial selalu dipertanyakan dan dipermasalahkan. Peneliti interpretif berusaha untuk memahami dasar dan sumber realitas sosial dengan menggali kesadaran manusia secara mendalam dan subjektif dalam upayanya mendapatkan makna dasar dari kehidupan sosial (Burrel dan Morgan, 2005). Demikian pula dengan penelitian ini, peneliti berusaha untuk mendapatkan pemahaman tentang kualitas audit BPK RI sebagai realitas sosial. Pemahaman tentang kualitas audit BPK RI berusaha diperoleh peneliti dengan cara menggali kesadaran peneliti secara mendalam dan subjektif, dan oleh karena itu peneliti menggunakan Hermeneutika Gadamerian.

Hermeneutika menurut Gadamer, lebih merupakan upaya memahami dan menginterpretasi satu teks (Sumaryono, 1999). Hermeneutika Gadamerian melibatkan bahasa, historikalitas, serta proses dialogis dialektis. Hermeneutika Gadamerian dipandang peneliti sebagai metode yang sesuai dengan penelitian ini, dengan mempertimbangkan beberapa hal. Pertama, sumber data utama yang digunakan dalam penelitian ini adalah teks yang disampaikan menggunakan bahasa. Kedua, kualitas audit BPK RI yang berusaha untuk dimaknai oleh peneliti adalah audit yang telah menghasilkan opini sebagai hasil akhir dari proses audit. Hal ini berarti bahwa proses audit telah selesai dilakukan oleh BPK RI, sehingga dapat dikatakan sebagai "sejarah". Label "peristiwa bersejarah" terhadap proses audit BPK RI, diperkuat dengan dibatasinya akses peneliti terhadap data, sehingga informasi yang tersedia sangat terbatas. Ketiga, untuk mendapatkan pemahaman, peneliti membandingkan antara apa yang ada dengan apa yang seharusnya ada, dan mencari semua jawaban atas pertanyaan-pertanyaan di dalam teks, yang mana proses ini menjadi proses dialogis dialektis.

Hermeneutika menurut Raharjo (2007) dipandang sebagai metode penafsiran yang cukup representatif dan komprehensif serta memiliki tingkat akurasi tinggi untuk mengolah teks (data). Lewat pernyataannya BPK RI mengklaim bahwa audit mereka berkualitas tinggi karena telah 
menerapkan Standar Pemeriksaan Keuangan Negara dengan baik. Hal tersebut memang sesuai dengan pernyataan Krishnan dan Schauer (2001) dalam (Steckel dkk., 2014), bahwa pekerjaan auditor memiliki kualitas tinggi apabila mereka patuh kepada seluruh standar yang relevan. Namun demikian, dari teks (data) yang dikumpulkan oleh peneliti menunjukkan kondisi yang sebaliknya.

Hermeneutika menurut Gadamer adalah suatu perjumpaan dengan das Sein lewat bahasa (Poespoprodjo, 1987). Bahasa menjadi ciri keberadaan manusia, dan hermeneutika digunakan untuk mengurai masalah filsafat tentang hubungan bahasa dengan das Sein, dengan pemahaman, dengan sejarah, eksistensi, dan realitas (Poespoprodjo, 1987). Manusia dan teks dihubungkan oleh bahasa, dan hanya dengan adanya bahasa, peleburan cakrawala antara manusia dan teks tersebut dimungkinkan. Gadamer menjelaskan konsepsi dari das Wirkungsgeschitliche Bewusstsein, bahwa hermeneutika adalah interaksi dialektik dengan tradisi yang disampaikan lewat teks, sehingga teks adalah bagian yang paling penting dalam upaya mencari pemahaman dengan Hermeneutika Gadamerian.

Dalam mencari pemahaman tentang kualitas audit BPK RI, langkah pertama yang dilakukan oleh peneliti yaitu, mencari sumber data utama dalam bentuk teks yang diharapkan dapat menjawab pertanyaan-pertanyaan peneliti, sebagai proses dialektik. Teks (data) yang digunakan oleh peneliti adalah dokumen resmi yang dikeluarkan oleh BPK RI seperti siaran pers yang dipublikasikan dalam situs resmi BPK RI, Laporan Hasil Pemeriksaan (LHP) atas Laporan Keuangan Pemerintah Pusat/Daerah, serta berita atau artikel yang dipublikasikan oleh media massa dalam jaringan.

Hermeneutika Gadamerian bertumpu pada dua pikiran pokok Heidegger, yakni bahwa pemahaman senantiasa memiliki prastruktur yaitu, Vorhabe (apa yang kita miliki), Vorsicht (apa yang kita lihat), dan Vorgriff (apa yang akan kita peroleh kemudian) (Sumaryono, 1999) yang terlibat dalam interpretasi, dan bahwa secara intrinsik Dasein (terjemahan bebas: keberadaan) manusia adalah historikal (Poespoprodjo, 1987). Seseorang memahami suatu situasi, suatu teks, atau suatu hal, tidak pernah dengan kesadaran kosong dan pasti telah memiliki perspektif atas sesuatu tersebut terlebih dahulu (Poespoprodjo, 1987). Interpretasi melibatkan subjektivitas berupa prasuposisi atas sesuatu yang diinterpretasikan. Heidegger (1960) dalam Poespoprodjo (1987) menyatakan bahwa "Interpretasi tidak pernah berupa suatu pemahaman tanpa prasuposisi terhadap sesuatu yang diberikan sebelumnya". Pertemuan antara peneliti dengan teks, berada di dalam konteks ruang dan waktu, berkaitan dengan cakrawala pengalaman dan minat dari peneliti.

Tidak ada penglihatan dan pemahaman yang murni terbebas dari sejarah dan tidak terikat dengan masa kini (Poespoprodjo, 1987). Pemahaman selalu melibatkan historikalitas, yang mana sesuatu yang ada pada masa kini hanya dapat dilihat dan dipahami dengan menggunakan prakonsepsi-prakonsepsi yang diwarisi dari masa lalu. Dialektika antara interpretator dengan teks akan selalu disertai dengan prasuposisi interpretator yang terbentuk oleh tradisi yang bersembunyi dalam bahasa. Bagi Heidegger dan Gadamer, bahasa, sejarah dan das Sein tidak hanya berkaitan, tetapi ketiganya melebur menjadi satu (Poespoprodjo, 1987). Interpretasi selalu melibatkan prasuposisi, terkait dengan masa kini, dan tidak pernah bersifat tetap atau fixed.

Teks dibentuk oleh sejarahnya, namun makna yang berusaha ditangkap interpretator dari teks adalah makna bagi interpretator, karena teks tersebut dilihat dalam cakrawala kesejarahan interpretator. Namun demikian, tidak berarti bahwa makna dalam teks bagi interpretator berbeda dengan makna bagi orang lain pada waktu-waktu sebelumnya. Hakikat suatu karya besar adalah menyingkap kebenaran realitas sehingga kebenaran hakikinya sesuai dengan hal yang sebenarnya, dan tugas dari interpretator adalah melacak kembali peristiwa yang muncul dan terlihat sebagai realitas (Poespoprodjo, 1987).

Hermeneutika menaruh minatnya pada masalah mengungkap kebenaran dalam teks, dan teks dapat dipahami ketika interpretator menyatu dalam masalah yang dikomunikasikan dalam teks (Poespoprodjo, 1987). Menyatu dalam hal ini bukan berarti interpretator keluar dari perspektifnya, namun lebih cenderung menarik teks ke dalam "dunia" interpretator dan menafsirkannya sesuai dengan perspektifnya. Dalam memahami teks, interpretator harus memiliki prasuposisi 
hermeunetika untuk merekonstruksi konteks sejarah. Namun demikian pemahaman tidak diperoleh melalui rekonstruksi menciptakan atau mengembalikan yang asli, tetapi dengan menyatukan diri ke dalam masalah dalam teks (Poespoprodjo, 1987).

Langkah kedua yang dilakukan peneliti adalah memunculkan prasuposisi-prasuposisi terkait dengan kualitas audit BPK RI berdasarkan pengalaman dan minat dari peneliti. Sebelum memunculkan prasuposisi, peneliti harus memiliki pemahaman terhadap filosofi auditing, kualitas audit, pemeriksaan keuangan (dasar hukum, ruang lingkup, tujuan, dan standarnya mulai dari perencanaan, pelaksanaan, hingga pelaporan), profil BPK RI (tugas dan wewenang, pemangku kepentingan, kedudukan dan peran), peraturan perundang-undangan yang terkait dengan pengelolaan keuangan negara/daerah, dan Standar Profesional Akuntan Publik (SPAP). Prasuposisi dari peneliti muncul dari tradisi yang menjadi cakrawala cara berpikir peneliti, yang secara umum mengacu kode etik dan standar audit yang harus dipatuhi atau kondisi yang ideal dalam praktik audit, dan secara khusus mengacu pada pengalaman yang dimiliki oleh peneliti.

Hermeneutika Gadamerian pada hakikatnya adalah dialektika struktur dari pengalaman yang berupa bentuk "tahu" yang jelas, historikal, dan berada di dalam ruang dan waktu (Poespoprodjo, 1987). Keberadaan historikalitas manusia tampil dalam kenyataan pengalaman dan pandangan. Pandangan selalu memuat suatu proses kembali dari sesuatu yang mana sering membuat orang menjadi buta dan terperangkap (Poespoprodjo, 1987). Hakikat wirkungsgeschichtlichen Bewusstsein adalah pengalamanlah yang meletakkan orang di dalam keterbukaan yang sebenarnya terhadap masa depan dan masa lalu (Poespoprodjo, 1987), yang artinya bahwa masa lalu dan masa depan hanya akan menjadi terbuka dan dapat dilihat oleh orangorang yang memiliki pengalaman.

Teks dipandang sebagai isi arti yang lepas dari segala ikatan dengan pihak-pihak yang memaksudkannya (Poespoprodjo, 1987), yang berarti bahwa dalam Hermeneutika Gadamerian, interpretator tidak berusaha untuk memahami maksud dari pembuat teks namun memahami isi dari teks itu sendiri dengan meleburkan cakrawala interpretator dengan teks. Manakala teks yang menyejarah diperlakukan sebagai sejarah saja, maka tradisi disamakan dengan sesuatu masa lalu, masa kini didogmatisasikan dan tidak dipertanyakan, padahal pertanyaan merupakan hal yang penting dalam Hermeneutika Gadamerian (Poespoprodjo, 1987). Gadamer menegaskan bahwa semua pengalaman ditransformasikan ke dalam struktur pertanyaan, karena tidak ada pengalaman tanpa adanya aktivitas bertanya, dan untuk dapat bertanya, kita harus mengerti bahwa kita tidak mengerti (Poespoprodjo, 1987).

Menempatkan seseorang dalam permainan bertanya dan menjawab, mengerti atau tidak mengerti, disebut juga dialektika, yang mana digambarkan oleh Plato bahwa melalui peristiwa pertanyaan, masalah diselidiki secara layak untuk dapat diperoleh hakikat yang sesungguhnya (Poespoprodjo, 1987). Dalam dialektika pertanyaan, berlangsung peristiwa hermeneutik (das hermeneuticsche Geschehen). Bertanya adalah membuka dan meletakkan diri di dalam keterbukaan, dan suatu pertanyaan pasti menuju pada suatu arah tertentu yang menunjukkan kepadanya jawaban serta jalan untuk mencapai tujuan (Poespoprodjo, 1987).

Untuk memahami suatu teks, seseorang harus merekonstruksi pertanyaan yang mana jawaban dari pertanyaan tersebut dapat diberikan oleh teks. Teks harus menjadi "kawan" dialog yang mengenali atau pertanyaan seseorang, dan dengan demikian teks dapat memberikan jawabannya (Poespoprodjo, 1987 : 106). Tujuan dialog atau dialektika bukan untuk memperlemah penuturan-penuturan dari kawan bicara, tetapi justru untuk memperkuatnya dengan menemukan kekuatan yang sesungguhnya di dalam masalahnya sendiri (Poespoprodjo, 1987). Setiap kalimat de facto adalah satu jawaban dari pertanyaan, maka arti setiap kalimat menunjukkan hubungan dengan pertanyaan yang diajukan, yang mana arti melebihi hal-hal yang terungkap secara eksplisit (Poespoprodjo, 1987).

Langkah ketiga yang dilakukan peneliti adalah mengajukan pertanyaan-pertanyaan, yang mana jawabannya dimiliki oleh teks yang dijadikan sebagai sumber data utama. Pertanyaanpertanyaan yang diajukan oleh peneliti didasari oleh historikalitas dari peneliti yang tercermin pada 
pengalaman dan pandangan yang dimiliki oleh peneliti. Dalam upaya untuk mendapatkan pemahaman tentang kualitas audit BPK RI, tujuan peneliti bukan untuk memahami maksud dari pembuat teks, namun lebih pada memahami isi teks yang diharapkan dapat memunculkan dan memperlihatkan kualitas audit BPK RI. Teks-teks yang menjadi sumber data utama yang digunakan dalam penelitian ini memiliki historikalitasnya masing-masing, oleh karena itu, pertanyaan yang diajukan oleh peneliti harus menyesuaikan dengan historikalitas dari teks tersebut, sehingga pertanyaan peneliti kepada masing-masing teks bisa berbeda karena setiap teks memiliki kemampuan yang berbeda dalam memberikan jawaban.

Langkah keempat adalah melakukan dialog antara peneliti dengan teks. Peneliti mencari jawaban atas pertanyaannya terhadap teks, dan jawaban bukan hanya yang secara de facto terungkap secara eksplisit dalam teks, melainkan juga hal yang dapat diungkap secara implisit. Peneliti mengakui adanya prasuposisi-prasuposisi yang dimilikinya, dan mencoba memasuki "dunia" dalam teks meski peneliti sadar bahwa prasuposisi-prasuposisi tersebut dapat mengacaukan dan menyebabkan salah paham terkait dengan pertanyaan dan jawaban dari pokok masalah (sachlich) atau pemahaman yang dicarinya di dalam teks. Untuk dapat menafsirkan kualitas audit BPK RI, peneliti tidak meninggalkan cakrawalanya tetapi memperluasnya sehingga dapat melebur dengan cakrawala teks, dan akhirnya mendapatkan pemahaman. Dalam dialektika pertanyaan dan jawaban yang dilakukan dalam struktur Hermeneutika Gadamerian, terjadilah die Horizontverschmelzung (fusi cakrawala), yang sekaligus merupakan bentuk dari penyingkapan ontologis.

Objek penelitian dalam penelitian ini adalah BPK RI, dengan didasari oleh melekatnya tugas dan fungsi untuk melakukan pemeriksaan pengelolaan dan tanggung jawab keuangan negara pada BPK RI. Tidak ada lembaga lain yang berwenang memeriksa pengelolaan dan tanggung jawab keuangan negara, selain BPK RI. Sumber data utama yang digunakan adalah dokumentasi dan rekaman arsip. Lofland dan Lofland (1984) dalam Moleong (2014) menyatakan bahwa katakata dan tindakan, merupakan sumber data utama dalam penelitian kualitatif. Data atau informasi dokumenter bisa menjadi bukti yang sangat relevan dengan setiap topik penelitian, seperti dalam bentuk pengumuman resmi, dokumen administratif, penelitian resmi yang terkait dengan objek penelitian yang sama, laporan peristiwa yang tertulis, atau kliping atau artikel yang muncul di media massa, yang mana dokumen-dokumen tersebut menyajikan data atau informasi secara eksplisit (Yin, 2015). Dokumen yang menjadi sumber data utama dalam penelitian ini adalah siaran pers yang dipublikasikan dalam situs resmi BPK RI, Laporan Hasil Pemeriksaan (LHP) atas Laporan Keuangan Pemerintah Provinsi EJ Tahun 2012, dan berita atau artikel yang dipublikasikan oleh media massa dalam jaringan.Rekaman arsip biasanya berupa rekaman aktivitas yang dilakukan oleh sebuah organisasi dalam periode tertentu, struktur organisasi, peta, data survei yang berkaitan dengan objek penelitian, atau rekaman pribadi (Yin, 2015). Bukti rekaman arsip yang digunakan peneliti adalah Ikhtisar Hasil Pemeriksaan Semester (IHPS) yang berisi informasi tentang rekapitulasi pelaksanaan pemeriksaan keuangan yang dilakukan oleh BPK RI dalam periode satu semester dan juga rekapitulasi opini yang diterima oleh setiap entitas yang diperiksa oleh BPK RI selama lima tahun terakhir.

\section{HASIL DAN PEMBAHASAN}

\section{Membedah LHP BPK RI sebagai Parameter Kualitas Audit}

Sepanjang tahun 2015, BPK RI telah melakukan 642 audit (pemeriksaan keuangan) atas laporan keuangan entitas pemerintah. Dengan asumsi BPK RI melakukan audit dalam jumlah yang konsisten setiap tahunnya, maka semenjak ditetapkannya Undang-Undang Nomor 15 Tahun 2006 tentang Badan Pemeriksa Keuangan sampai dengan saat ini (kurang lebih 10 tahun), BPK RI telah melakukan 6.420 audit dan menghasilkan 19.260 LHP (setiap audit, BPK menghasilkan tiga laporan, yaitu LHP atas Laporan Keuangan, LHP atas Sistem Pengendalian Intern, dan LHP atas 
Kepatuhan terhadap Perundang-undangan), sehingga sangat tidak mungkin untuk melakukan analisis terhadap seluruh LHP tersebut.

Dalam penelitian ini, peneliti hanya memilih satu LHP BPK RI yaitu LHP atas Laporan Keuangan Pemerintah Provinsi EJ Tahun 2012, yang dipilih karena opininya mengalami penurunan dalam rentang waktu tiga tahun berturut-turut. Laporan Keuangan Pemerintah Provinsi EJ mendapatkan opini WTP pada tahun 2012, opini Wajar Tanpa Pengecualian - Dengan Paragraf Penjelas (WTP-DPP) pada tahun 2013, dan opini Wajar Dengan Pengecualian (WDP) pada tahun 2014. Hal yang menarik adalah Laporan Keuangan Pemerintah Provinsi EJ Tahun 2012 telah mendapatkan opini WTP, yang berarti bahwa secara umum Laporan Keuangan Pemerintah Provinsi EJ Tahun 2012 telah sesuai dengan Standar Akuntansi Pemerintahan (SAP) dan pengungkapan yang cukup, telah mematuhi peraturan perundang-undangan, dan telah memiliki sistem pengendalian intern yang efektif. Namun secara berturut-turut pada dua tahun berikutnya, BPK RI "menurunkan" opini Laporan Keuangan Pemerintah Provinsi EJ. Kondisi tersebut menimbulkan pertanyaan bagi peneliti, "ada apa dengan audit (pemeriksaan keuangan) BPK RI atas Laporan Keuangan Provinsi EJ Tahun 2012?”, oleh karena itu, Laporan Keuangan Provinsi EJ Tahun 2012 dipilih peneliti untuk dijadikan sampel dalam menilai kualitas audit BPK RI.Agar lebih mudah dalam memahami analisis yang dilakukan, berikut ini adalah salah satu temuan pemeriksaan dalam LHP atas Kepatuhan terhadap Peraturan Perundang-undangan Provinsi EJ Tahun 2012:

"Penerima Hibah Sebesar Rp51.306.735.757,00 Belum Menyampaikan Laporan Pertanggungjawaban kepada Gubernur"

Pada TA 2012, Pemerintah Provinsi EJ menganggarkan Belanja Hibah sebesar Rp4.092.242.765.000,00 dan telah direalisasikan sebesar Rp3.865.450.909.599,68. Dalam merealisasikan kedua belanja tersebut, Pemerintah Provinsi EJ memiliki verifikatur pada tingkat Satuan Kerja Perangkat Daerah (SKPD)/Biro sebagai Kuasa Pejabat Pengelola Keuangan Daerah (KPPKD) Belanja Hibah yang bertanggung jawab untuk melakukan verifikasi atas usulan, kelengkapan persyaratan administrasi permohonan bantuan, penetapan penerima, pemrosesan naskah perjanjian atas program kegiatannya sampai dengan pertanggungjawabannya.

Hasil pemeriksaan atas bukti pertanggungjawaban/Laporan Pertanggungjawaban (LPJ) dari masing-masing penerima hibah yang telah disampaikan kepada masing-masing KPPKD menunjukkan bahwa sampai dengan saat pemeriksaan berakhir pada tanggal 5 Mei 2013, terdapat 803 penerima hibah sebesar Rp51.306.735.757,00 yang belum menyampaikan laporan pertanggungjawaban penggunaan dana hibah untuk dilakukan verifikasi kesesuaian pertanggungjawaban dengan proposal yang direncanakan dalam Naskah Perjanjian Hibah Daerah. Rincian nilai hibah yang penerima hibahnya belum menyampaikan LPJ untuk setiap SKPD sebagai leading sector-nya pada tabel berikut:

Tabel 2

Rincian Penerima Hibah

\begin{tabular}{|c|l|c|c|}
\hline No. & \multicolumn{1}{|c|}{ SKPD Leading Sector } & Jumlah Penerima Hibah & Belum Menyampaikan LPJ (Rp) \\
\hline 1. & Dinas Pendidikan & 714 & $46.372 .735 .757,00$ \\
\hline 2. & $\begin{array}{l}\text { Biro Administrasi } \\
\text { Kemasyarakatan }\end{array}$ & 4 & $175.000 .000,00$ \\
\hline 3. & $\begin{array}{l}\text { Biro Administrasi } \\
\text { Pembangunan }\end{array}$ & 32 & $2.109 .000 .000,00$ \\
\hline 4. & $\begin{array}{l}\text { Biro Administrasi } \\
\text { Perekonomian }\end{array}$ & 53 & $2.650 .000 .000,00$ \\
\hline \multicolumn{2}{r}{ Jumlah } & 803 & $51.306 .735 .757,00$ \\
\hline
\end{tabular}


Kondisi tersebut tidak sesuai dengan:

a. Peraturan Menteri Dalam Negeri 13 Tahun 2006 tentang Pedoman Pengelolaan Keuangan Daerah pada Pasal 133 ayat (2) yang menyatakan bahwa penerima subsidi, hibah, bantuan sosial, dan bantuan keuangan bertanggung jawab atas penggunaan uang/barang dan/atau jasa yang diterimanya dan wajib menyampaikan laporan pertanggungjawaban penggunaannya kepada Kepala Daerah;

b. Peraturan Menteri Dalam Negeri 32 Tahun 2011 tentang Tentang Pedoman Pemberian Hibah dan Bantuan Sosial Yang Bersumber Dari Anggaran Pendapatan dan Belanja Daerah sebagaimana telah diubah dengan Peraturan Menteri Dalam Negeri Nomor 39 Tahun 2012 tentang Perubahan atas Peraturan Menteri Dalam Negeri Nomor 32 Tahun 2011 pada Pasal 19 ayat (3) yang menyatakan bahwa pertanggungjawaban sebagaimana dimaksud pada ayat (2) huruf a dan huruf $\mathrm{b}$ disampaikan kepada kepala daerah paling lambat tanggal 10 bulan Januari tahun anggaran berikutnya, kecuali ditentukan lain sesuai peraturan perundang-undangan;

c. Peraturan Gubernur EJ Nomor 17 Tahun 2011 tentang Pedoman Pengelolaan Belanja Subsidi, Hibah, Bantuan Sosial, Bagi Hasil, Bantuan Keuangan, Belanja Tidak Terduga dan Pengeluaran Pembiayaan Provinsi EJ Tahun Anggaran 2011 pada:

1) Pasal 15 ayat (1) yang menyatakan bahwa penerima Belanja Subsidi, Hibah, Bantuan Sosial dan Bantuan Keuangan bertanggung jawab atas penggunaan uang/barang dan /atau jasa yang diterimanya dengan berpedoman pada ketentuan perundang-undangan dan wajib menyampaikan laporan pertanggung jawaban penggunaannya kepada Gubernur EJ;

2) Pasal 15 ayat (2) yang menyatakan bahwa pertanggungjawaban sebagaimana dimaksud pada ayat (1) berupa Laporan Realisasi Penggunaan Uang/Barang dan/atau Jasa.

Akibatnya realisasi Belanja Hibah sebesar Rp51.306.735.757,00 belum dapat diyakini kesesuaian penggunaannya dengan proposal atau naskah hibahnya.Kondisi tersebut disebabkan Kepala Dinas Pendidikan, Kepala Biro Administrasi Kemasyarakatan, Kepala Biro Administrasi Pembangunan dan Kepala Biro Administrasi Perekonomian belum optimal dalam pengendalian terhadap penyampaian laporan pertanggungjawaban penggunaan hibah oleh penerima hibah.Atas kondisi tersebut, masing-masing Kepala SKPD sebagai Kuasa PPKD (KPPKD) belanja hibah memberikan penjelasan bahwa:

a. Kepala Dinas Pendidikan menyatakan bahwa atas keterlambatan penyampaian pertanggungjawaban hibah disebabkan antara lain karena proses verifikasi usulan penerima hibah membutuhkan waktu yang lama, adanya perubahan usulan penerima hibah dari Dinas Pendidikan Kabupaten/Kota di Provinsi EJ dan adanya pelaksanaan kegiatan pembelajaran yang membutuhkan waktu 6 bulan;

b. Kepala Biro Administrasi Kemasyarakatan menyatakan bahwa atas keterlambatan penyampaian pertanggungjawaban hibah telah dilakukan upaya dan akan bekerja sama dengan instansi teknis terkait untuk menyelesaikan laporan pertanggung jawaban;

c. Kepala Biro Administrasi Pembangunan menyatakan bahwa atas keterlambatan penyampaian pertanggungjawaban hibah telah dilakukan upaya monitoring ke lapangan dan memberikan teguran kepada masing-masing penerima hibah;

d. Kepala Biro Administrasi Perekonomian menyatakan bahwa atas keterlambatan penyampaian pertanggungjawaban hibah telah dilakukan teguran kepada masing-masing kelompok masyarakat, hal tersebut disebabkan karena banyak kelompok masyarakat yang sudah memesan barang namun masih belum tersedia (indent) dan banyak yang kurang tertib administrasi

BPK RI merekomendasikan kepada Gubernur EJ agar:

a. Memerintahkan kepada Kepala Dinas Pendidikan, Kepala Biro Administrasi Kemasyarakatan, Kepala Biro Administrasi Pembangunan dan Kepala Biro Administrasi Perekonomian untuk meminta laporan pertanggungjawaban penggunaan dana hibah kepada 803 penerima hibah sebesar Rp51.306.735.757,00; 
b. Memerintahkan Inspektur Provinsi EJ untuk melakukan pemeriksaan kesesuaian penggunaan dana hibah oleh penerima hibah dengan naskah perjanjian hibah setelah laporan pertanggungjawaban penggunaan dana hibah tersebut diperoleh dari penerima hibah dan melaporkan hasilnya kepada BPK RI.”

Dari uraian temuan pemeriksaan tersebut, dapat kita ketahui bahwa anggaran untuk Belanja Hibah sangat besar, yaitu Rp4.092.242.765.000,00 atau 35,03\% dari total Anggaran Belanja Provinsi EJ tahun 2012 yaitu sebesar Rp11.681.141.999.952,00. Sedangkan realisasi Belanja Hibah adalah sebesar Rp3.865.450.909.599,68 atau 94,46\% dari total anggaran Belanja Hibah. Proporsi anggaran Belanja Hibah terhadap total anggaran belanja sangat besar, sehingga seharusnya mendapatkan perhatian lebih pada saat dilakukannya pemeriksaan karena pengaruhnya sangat material terhadap laporan keuangan secara keseluruhan.

Dilihat dari perspektif risiko, belanja hibah memiliki risiko inheren yang sangat tinggi, yang disebabkan belanja hibah memiliki kecenderungan untuk dianggarkan dalam jumlah besar untuk selanjutnya diserahkan kepada pihak ketiga dalam nominal yang relatif kecil sehingga akan melibatkan banyak penerima hibah. Dengan jumlah penerima hibah yang banyak, secara tidak langsung meningkatkan risiko kecurangan terhadap pengelolaan Belanja Hibah. Entitas pemerintah yang diperiksa pasti tahu bahwa pemeriksa tidak mungkin memeriksa seluruh populasi, dan hanya mengambil sebagian kecil saja sebagai sampel, sehingga sangat besar kemungkinan bahwa mereka akan memanfaatkan situasi tersebut. Hal ini dapat dibuktikan dengan banyaknya kasus korupsi yang melibatkan Belanja Hibah pada Pemerintah Daerah, baik yang diekspos oleh media massa maupun yang tidak.

Dari sisi pengendalian intern, disebutkan dalam LHP bahwa Pemerintah Provinsi EJ telah memiliki verifikatur yang bertanggung jawab untuk melakukan verifikasi dalam mengelola belanja hibah, yang mana hal itu menunjukkan bahwa telah ada sistem pengendalian intern (SPI) dalam pengelolaan dana hibah. Mengenai efektivitas sistem pengendalian, karena dalam LHP atas Sistem Pengendalian Intern tidak ada temuan pemeriksaan yang berkaitan dengan Belanja Hibah, maka dapat diasumsikan pemeriksa BPK RI menganggap bahwa SPI belanja hibah telah efektif. Pertanyaan yang muncul adalah apabila SPI telah efektif bagaimana kondisi ini bisa terjadi? Sementara kondisi ini secara jelas menunjukkan bahwa sebenarnya ada kelemahan SPI. Berdasarkan analisis yang dilakukan oleh peneliti, kelemahan SPI dalam pengelolaan Belanja Hibah, yaitu Belanja Hibah diserahkan seluruhnya sekaligus kepada penerima hibah. Hal ini membuat penerima hibah telah mendapatkan apa yang diharapkan, sehingga mengabaikan apa yang menjadi tanggung jawabnya. Atas dasar tersebut, peneliti berpendapat bahwa kelemahan pada rancangan SPI pengelolaan Belanja Hibah menyebabkan risiko pengendalian yang tinggi, oleh karena itu pemeriksaan harus dilakukan pada lingkup yang lebih luas dan lebih mendalam.

Berdasarkan penilaian risiko inheren dan risiko pengendalian tersebut, seharusnya pemeriksa BPK RI memberikan penilaian dengan risiko tinggi terhadap Belanja Hibah, dan meresponsnya dengan melakukan pemeriksaan yang lebih dalam. Namun hasil pemeriksaan tidak menunjukkan hal yang demikian, hal ini dapat diduga dari temuan pemeriksaan paragraf kedua, terdapat kalimat "Dari hasil pemeriksaan atas bukti pertanggungjawaban/Laporan Pertanggungjawaban (LPJ) ...", yang menunjukkan bahwa prosedur pemeriksaan yang dilakukan oleh pemeriksa hanya sebatas pengujian atas dokumen. Dugaan tersebut didukung juga dengan paragraf rekomendasi poin $b$, yang mana BPK RI merekomendasikan Gubernur EJ agar memerintahkan Inspektur Provinsi EJ untuk memeriksa Belanja Hibah tersebut.

Prosedur pemeriksaan pengujian atas dokumen dalam kasus Belanja Hibah ini, dapat dilakukan untuk mendapatkan keyakinan atas asersi kelengkapan, namun tidak terhadap asersi lainnya seperti asersi keberadaan atau keterjadian, serta asersi penilaian dan pengalokasian, sehingga dapat disimpulkan bahwa bukti pemeriksaan tidak cukup. Bukti pemeriksaan adalah dasar bagi pemeriksa untuk memberikan opini auditnya, sehingga bukti yang tidak cukup dan tidak relevan akan meningkatkan risiko audit atau auditor salah dalam memberikan opini. Pemeriksa seharusnya melakukan prosedur pemeriksaan lainnya untuk mendapatkan bukti tambahan seperti 
inspeksi (pemeriksaan fisik) dan bertanya atau wawancara, untuk mendapatkan keyakinan terhadap seluruh asersi. Bukti memiliki berbanding lurus dengan risiko, yang mana semakin besar risiko audit maka bukti yang harus diperlukan semakin banyak (Tuankotta, 2015 : 84).

Laporan Keuangan Pemerintah Provinsi EJ Tahun 2012 menerima opini Wajar Tanpa Pengecualian (WTP) dari BPK RI meskipun terdapat permasalahan yang menurut peneliti sangat critical, yaitu ketidakcukupan bukti, serta risiko kecurangan yang sangat tinggi. Belanja Hibah yang belum disampaikan pertanggungjawabannya oleh penerima hibah kepada Gubernur EJadalah sebesar Rp51.306.735.757,00 atau 1,33\% dari realisasi Belanja Hibah, atau 1,25\% dari anggaran Belanja Hibah, atau 0,44\% dari total anggaran belanja Provinsi EJ. Pemeriksa BPK RI tidak dapat meyakini Belanja Hibah tersebut, hal ini dapat dilihat dari paragraf akibat, yang isinya adalah sebagai berikut:

"Akibatnya realisasi Belanja Hibah sebesar Rp51.306.735.757,00 belum dapat diyakini kesesuaian penggunaannya dengan proposal atau naskah hibahnya.".

Kondisi ini tentu saja menimbulkan pertanyaan bagi peneliti, bagaimana bisa BPK RI tidak dapat meyakini suatu transaksi atau saldo akun dalam laporan keuangan, tetapi memberikan keyakinan kepada pengguna laporan keuangan bahwa laporan keuangan tersebut telah disajikan secara wajar sebagaimana tercermin pada opininya? Satu-satunya alasan teknis yang dapat diperkirakan oleh peneliti adalah bahwa temuan pemeriksaan ini tidak dianggap material. Nilai sebesar Rp51.306.735.757,00 memang relatif sangat kecil apabila dibandingkan dengan total APBD Provinsi EJ Tahun 2012, dan tidak akan menjadi material apabila hanya dibandingkan dengan Tolerable Misstatement (TM) atau Tolerable Error (TE), terlebih lagi dengan Planning Materiality (PM). Akan tetapi, penetapan materialitas seharusnya bukan hanya didasarkan pada segi kuantitatif, namun juga secara kualitatif, yang dinyatakan dalam Keputusan BPK RI Nomor 5/K/I-XIII.2/10/2013 tentang Petunjuk Teknis Penetapan Batas Materialitas Pemeriksaan Keuangan, bahwa:

"Dalam sektor publik, materialitas tidak hanya dinilai dari segi kuantitatif tetapi juga segi kualitatif, terutama terkait dengan tingkat kepentingan para pihak terhadap laporan keuangan pemerintah. Tingkat ketaatan pemerintah terhadap Peraturan Perundang-undangan memiliki nilai kepentingan lebih tinggi dibandingkan kemampuan pemerintah menghasilkan dan mempertahankan surplus anggaran, sehingga pelanggaran terhadap Peraturan Perundang-undangan, seperti adanya transaksi yang berindikasi korupsi berapa pun nilai nominalnya, baik yang berdampak langsung maupun tidak langsung terhadap kewajaran laporan keuangan dapat mempengaruhi penilaian materialitas secara kualitatif.”.

Dalam kasus lain, yaitu pada sektor privat, Tuanakotta $(2015,130)$ memberikan pernyataan dan salah satu contoh penetapan materialitas dari segi kualitatif, yaitu sebagai berikut:

"Materialitas dalam makna kualitatif berkenaan dengan sifat atau kondisi (circumstance) dari salah saji. Lihat laporan audit PwC dalam sketsa audit Tesco. PwC menetapkan materialitas secara kuantitatif sebesar £150 juta (sekitar 5\% dari laba sebelum pajak). PwC menetapkan materialitas secara kualitatif dengan keterangan: “... We would report to them misstatements identified during our audit above $£ 7$ million as well as misstatements below that amount ... , ... for qualitative reasons.". ... maka jumlah salah saji yang dianggap material ini, berada di bawah angka materialitas kuantitatif (£7 juta dibandingkan dengan $£ 150$ juta dalam kasus Tesco)."

Temuan pemeriksaan atas Belanja Hibah merupakan ketidakpatuhan Pemerintah Provinsi EJ terhadap Peraturan Perundang-undangan, yang tidak serta merta dapat dianggap sebagai tindak pidana korupsi, karena tindak pidana korupsi berdasarkan Undang-Undang Nomor 31 Tahun 1999 (UU 31/1999) tentang Pemberantasan Tindak Pidana Korupsi harus memenuhi beberapa unsur, yaitu perbuatan melawan hukum, memperkaya diri sendiri atau orang lain atau suatu korporasi, dan 
dapat merugikan keuangan negara atau perekonomian negara. Namun demikian, temuan pemeriksaan atas Belanja Hibah bisa diasumsikan sebagai indikasi korupsi jika dilihat dari tingginya risiko kecurangan pada pos atau akun tersebut, serta terpenuhinya salah satu unsur tindak pidana korupsi yaitu perbuatan melawan hukum meskipun nantinya harus dibuktikan lebih lanjut.

Dalam pertimbangan kualitatif dalam penetapan materialitas, frase “... sehingga pelanggaran terhadap Peraturan Perundang-undangan, seperti adanya transaksi yang berindikasi korupsi berapa pun nilai nominalnya, ...", secara jelas menunjukkan bahwa temuan pemeriksaan Belanja Hibah seharusnya menjadi temuan yang material. Meskipun tidak material dari segi kuantitatif karena nilainya yang lebih rendah dari angka materialitas, temuan pemeriksaan Belanja Hibah material dari segi kualitatif karena terdapat pelanggaran terhadap Peraturan Perundang-undangan dan terdapat indikasi korupsi, sehingga seharusnya pemeriksa BPK RI mengecualikan Belanja Hibah serta tidak memberikan opini WTP atas Laporan Keuangan Pemerintah Provinsi EJ Tahun 2012. Di samping itu, BPK RI seharusnya menindak lanjuti temuan pemeriksaan tersebut dengan pemeriksaan dengan tujuan tertentu untuk membuktikan ada atau tidaknya Kerugian Daerah dan ada atau tidaknya tindak pidana korupsi.

\section{Makna Kata "Wajar" dalam Opini Audit}

Opini Wajar Tanpa Pengecualian (WTP) atas laporan keuangan menjadi target bagi seluruh entitas pemerintah, baik pusat maupun daerah. Opini WTP seolah menjadi "cap" bagi pemerintah bahwa mereka telah mengelola Keuangan Negara/Daerah dengan baik, serta tidak ada korupsi di dalamnya. Rakyat selalu berharap bahwa keuangan negara/daerah dikelola dengan baik, dan opini atas laporan keuangan entitas pemerintah merupakan satu-satunya sumber informasi bagi rakyat terkait dengan pengelolaan keuangan negara/daerah. Oleh karena itu, auditor dituntutagar mampu memberikan informasi yang meminimisasi perbedaan antara kondisi ekonomi yang dilaporkan dengan kebenaran (Watkins dkk., 2004)

Kadang kala harapan tidak sesuai dengan realitas, hal ini juga terjadi dalam konteks audit, yang mana dalam penelitian Liggio (1974) disebut sebagai audit expectation gap, yaitu perbedaan antara tingkat kinerja yang diekspektasikan oleh pengguna laporan keuangan dengan kinerja seperti yang dibayangkan oleh akuntan (auditor) independen. Berdasarkan penelitian Porter (1993), ada dua komponen utama penyebab adanya gap tersebut, yaitu reasonableness gap dan performance gap, yang mana performance gap dibagi lagi menjadi dua yaitu: standar yang kurang baik apabila standar profesional auditor ternyata tidak mampu memenuhi ekspektasi publik, sehingga meskipun auditor telah melakukan seluruh tugas yang mana telah dinyatakan dalam standar profesional auditor, audit expectation gap akan tetap ada; dan kinerja yang kurang baik, apabila kinerja auditor yang dirasakan oleh publik tidak sesuai dengan yang diekspektasikan oleh publik.

Beberapa penelitian terkait dengan audit expetation gap dilakukan oleh Fadzly dan Ahmad (2004), Alleyne dan Howard (2005), dan Djamil (2006), secara umum hasil penelitian menunjukkan bahwa terdapat kesenjangan antara stakeholders dengan auditor terkait dengan tanggung jawab auditor, yang mana stakeholders memiliki harapan bahwa auditor bertanggung jawab untuk mendeteksi kecurangan sehingga dapat memberikan keyakinan bahwa informasi dalam laporan keuangan telah disajikan secara "benar dan wajar". Namun penelitian Lin dan Chen (2004) menunjukkan hasil yang berbeda, yaitu auditor dan penerima manfaat dari audit di Tiongkok, sepakat bahwa secara umum fungsi audit harus dapat meningkatkan kebenaran dan reliabilitas dari laporan keuangan (Lin dan Chen, 2004). Sedangkan penelitian Yuliati dkk. (2007) pada BPK RI, menunjukkan bahwa tidak terdapat audit expectation gap atas tanggung jawab auditor untuk mendeteksi dan melaporkan kecurangan, serta untuk mempertahankan sikap independen.

Hasil penelitian Yuliati dkk. (2007) menunjukkan tidak ada audit expectation gap antara BPK RI dan pengguna laporan keuangan, maka seharusnya terdapat kesepahaman bahwa BPK RI bertanggung jawab untuk mendeteksi dan melaporkan kecurangan (korupsi) pada saat melakukan audit (pemeriksaan keuangan) atas laporan keuangan entitas pemerintah. Namun demikian, peneliti 
menemukan berita, yang dalam sudut pandang peneliti, berita tersebut seolah menunjukkan upaya BPK RI "melepaskan" tanggung jawabnya dari kewajiban untuk mendeteksi dan melaporkan kecurangan. Berikut ini adalah dua berita terkait yang disajikan beserta konteks yang melingkupinya:
"Ketua Badan Pemeriksa Keuangan (BPK), Hadi Poernomo mengingatkan bahwa opini wajar tanpa pengecualian (WTP) yang diperoleh suatu entitas, tidak menjamin entitas itu bersih dari tindak pidana korupsi. "Tetap bisa terjadi korupsi di entitas yang memperoleh opini WTP karena bisa terjadi konspirasi," kata Hadi Poernomo dalam Rapat Anggota V Ikatan Akuntan Indonesia Kompartemen Akuntan Sektor Publik (IAI-KASP) di Gedung Badan Pengawasan Keuangan dan Pembangunan (BPKP) Jakarta, Selasa. Hadi Poernomo menyebutkan, opini yang dikeluarkan BPK merupakan penilaian atas kewajaran penyajian laporan keuangan. "Jadi yang kita nilai kewajaran, bukan kebenaran," kata Hadi Poernomo." (antaranews.com, 2014).
"Kepala Sub Auditorat Bali II Badan Pemeriksa Keuangan Perwakilan Provinsi Bali, Paula Henry Simatupang mengatakan, "Pemerintah daerah yang telah meraih opini Wajar Tanpa Pengecualian (WTP) bukan berarti bebas dari penyimpangan keuangan. Wajar Tanpa Pengecualian (WTP) ini merupakan prestasi tertinggi dalam pengelolaan keuangan. WTP bukanlah kebenaran tapi kewajaran. Oleh karena itu, walaupun sudah WTP belum tentu bebas dari kecurangan ataupun penyimpangan." (okezone.com 2016).

Dalam wacana di atas, BPK RI secara jelas menyatakan bahwa proses pemeriksaan yang mereka lakukan bukan untuk menilai kebenaran tetapi hanya sebatas kewajaran. Dalam sudut pandang peneliti, kata "kewajaran" dimaknai BPK RI dalam arti sempit, yaitu hanya sebatas kesesuaian dengan standar akuntansi pemerintahan. Di samping itu, BPK RI secara jelas menolak tanggung jawabnya untuk mengungkapkan kebenaran (termasuk mendeteksi dan melaporkan kecurangan), dalam melakukan pemeriksaan pengelolaan dan tanggung jawab keuangan negara.

Omoteso (2006) menyatakan bahwa audit eksternal dilakukan untuk menghasilkan opini apakah laporan keuangan telah menyajikan "gambaran yang benar dan wajar" dan telah disusun sesuai dengan kerangka kerja pelaporan (Omoteso dan Obalola, 2014). Unqualified audit reports mengindikasikan bahwa laporan keuangan telah menyajikan secara benar dan wajar atas posisi keuangan dan kinerja perusahaan (Mak dkk., 2005), dan untuk dapat memberikan "gambaran benar dan wajar", auditor harus memastikan bahwa substansi lebih diutamakan dibanding bentuk (substance over form) (European Commission, 2010 dalam Steckel dkk., 2014). Bahkan laporan keuangan di Inggris diharuskan oleh hukum untuk menyajikan pandangan yang benar dan wajar mengenai kondisi kliennya (Chastney, 1975 dalam Riahi-Belkaoui, 2004), dan laporan auditnya tidak menyatakan secara eksplisit tentang "kesesuaian dengan prinsip akuntansi yang diterima umum", tetapi lebih kepada menyatakan bahwa akun menunjukkan "gambaran yang benar dan wajar" dari kondisi keuangan perusahaan (Martens dan McEnroe, 1992).

Kata "benar" dan "wajar" akan menimbulkan kebingungan bagi penyusun atau pengguna laporan keuangan apabila belum didefinisikan secara komprehensif. Nobes (1981) dalam RiahiBelkaoui (2004) melakukan penelitian tentang interpretasi kata "benar" dan "wajar" oleh partner teknis dari 20 kantor akuntan publik terbesar di Inggris, yang memberikan pengertian untuk kata "benar" yaitu: berdasarkan atas fakta, fakta yang tidak terdistorsi, mematuhi aturan, benar, objektif, tidak bertentangan dengan fakta, benar dalam batasan material, akurasi faktual, dan ketaatan pada peristiwa; sedangkan pengertian untuk kata "wajar" yaitu: tidak menyesatkan, substance over form (substansi di atas bentuk), pencerminan yang tepat, konsisten dengan kenyataan yang mendasari, menempatkan sesuatu dalam konteks yang benar, kemampuan memahami apa yang sebenarnya terjadi, sesuai dengan aturan dalam konteksnya, memberikan kesan yang tepat, masuk akal, dan apakah pembaca dapat menerima pesan yang benar. 
Lee (1994) menyatakan bahwa "benar dan wajar" di Inggris dan "disajikan wajar" di Amerika Serikat hanyalah "label" dari laporan keuangan, yang mana label tersebut merupakan inti dari opini auditor (Martinis dan Burrowes, 1996). Auditor seharusnya menggunakan professional judgement dalam menentukan apakah laporan keuangan telah "disajikan secara wajar", yaitu tidak hanya harus menentukan kesesuaiannya dengan prinsip akuntansi yang diterima umum, tetapi juga memutuskan bahwa tidak ada penyesatan yang disebabkan oleh kegagalan dalam mencerminkan "substansi" dari transaksi bisnis yang disajikan dalam laporan keuangan (Martens dan McEnroe, 1992). Jadi pada prinsipnya, "penyajian wajar" atau "gambaran benar dan wajar" memiliki makna yang sama, yaitu mempertimbangkan substansi serta standar pelaporan, yang mana kedua hal tersebut tidak dapat dipisahkan dalam merumuskan opini audit.

Pada sektor publik di Indonesia, opini sangat identik dengan kewajaran dibandingkan dengan kebenaran, karena opini memang diungkapkan secara eksplisit dengan penggunaan kata "wajar". Meskipun demikian, seharusnya pemeriksaan keuangan negara tidak serta merta mengabaikan kebenaran atau substansi dari laporan keuangan entitas pemerintah yang diaudit. Dalam proses audit (pemeriksaan keuangan) yang sesuai dengan Standar Pemeriksaan Keuangan Negara (SPKN), BPK RI seharusnya mendeteksi adanya kecurangan dan kemudian mengungkapnya sebagai wujud dari kata "wajar. Oleh karena itu, pembatasan "wajar" yang hanya sebatas sesuai dengan standar akuntansi pemerintahan, berarti merupakan pelanggaran atau ketidakpatuhan terhadap standar audit. Dengan kondisi demikian, peneliti kemudian memiliki pertanyaan yang sama dengan responden pada penelitian Alleyne dan Howard (2005 : 292), “... then, why pay for an audit?".

\section{SIMPULAN DAN SARAN}

Mengacu pada rumusan permasalahan penelitian, dapat disimpulkan bahwa kualitas audit (pemeriksaan keuangan) BPK RI tidak sesuai dengan klaimnya. Hasil penelitian menunjukkan bahwa masih terdapat audit (pemeriksaan keuangan) BPK RI yang tidak patuh terhadap standar audit, yang dibuktikan dengan hasil analisis terhadap LHP atas Laporan Keuangan Pemerintah Provinsi EJ Tahun 2012. Hasil analisis menunjukkan bahwa terdapat penilaian dan respons risiko yang tidak tepat, kurangnya atau ketidakcukupan bukti, serta mengabaikan penilaian materialitas secara kualitatif. Di samping itu, pembatasan "kewajaran" hanya sebatas sesuai dengan standar akuntansi pemerintah tanpa mempertimbangkan "kebenaran" (mendeteksi dan melaporkan kecurangan), juga merupakan merupakan ketidakpatuhan terhadap SPKN, yang selanjutnya mempengaruhi kualitas audit (pemeriksaan keuangan) BPK RI.

Secara teoretis, penelitian ini memberikan bukti bahwa ketidakpatuhan auditor terhadap standar audit, menjadi salah satu penyebab rendahnya kualitas audit yang selanjutnya dapat mengakibatkan kegagalan audit atau auditor memberikan opini yang tidak tepat atas laporan keuangan yang diaudit. Sedangkan secara praktis, penelitian ini menunjukkan bahwa masih terdapat kelemahan dalam praktik audit (pemeriksaan keuangan) BPK RI, sehingga diharapkan BPK RI dapat merespons dengan tepat agar tujuan audit (pemeriksaan keuangan) negara dapat tercapai. Di samping itu, audit (pemeriksaan keuangan) yang berkualitas akan menghasilkan opini yang tepat dan menjadi simbol "kebenaran dan kewajaran" laporan keuangan, sehingga rakyat dapat mengetahui bagaimana Keuangan Negara/Daerah dikelola dan dipertanggung jawabkan oleh Pemerintah.

Keterbatasan dalam penelitian ini adalah peneliti tidak mendapatkan akses terhadap Kertas Kerja Pemeriksaan (KKP) sebagai pendukung dari historikalitas teks dari LHP yang dianalisis. Hal tersebut memang diatur dalam Peraturan Badan Pemeriksa Keuangan RI Nomor 3 Tahun 2011 tentang Pengelolaan Informasi Publik pada Badan Pemeriksa Keuangan yang mengecualikan informasi yang terkait dengan proses pemeriksaan. Oleh karena itu, disarankan bagi peneliti selanjutnya untuk dapat berupaya mendapatkan akses terhadap Kertas Kerja Pemeriksaan (KKP) dan wawancara kepada pemeriksa BPK RI. 


\section{DAFTAR RUJUKAN}

Alim, M.N., Hapsari, T. \& Purwanti, L., 2007. Pengaruh kompetensi dan independensi terhadap kualitas audit dengan etika auditor sebagai variabel moderasi. Simposium Nasional Akuntansi X, (8), pp.1-26.

Alleyne, P. \& Howard, M., 2005. An Exploratory Study of Auditors Responsibility for Fraud Detection in Barbados. Managerial Auditing Journal, 20(3), pp.284-303.

antaranews.com, 2014. BPK: Opini WTP Tidak Jamin Tidak Ada Korupsi. antaranewes.com. Tersedia di: http://www.antaranews.com/print/265960/bpk?opini?wtp?tidak?jamin?tidak? ada?korupsi (Diakses pada 13 Agustus 2016).

Beasley, M.S. et al., 2013. An Analysis of Alleged Auditor Deficiencies in SEC Fraud Investigations: 1998 - 2010. Center for Audit Quality.

BPK RI, 2011. Siaran Pers: Opini WTP Tidak Menjamin Tidak Ada Korupsi. Badan Pemeriksa Keuangan Republik Indonesia. Tersedia di: http://www. bpk.go.id/news/opini-wtp-tidakmenjamin-tidak-ada-korupsi.

BPK RI, 2015a. BPK Lakukan Pemeriksaan Keuangan Sesuai Dengan Standar Yang Berlaku. Tersedia di: http://www.bpk.go.id/news/bpklakukanpemeriksaankeuangansesuaidenganstan daryangberlaku

BPK RI, 2015b. Ikhtisar Hasil Pemeriksaan Semester (IHPS) 1 Tahun 2015.

BPK RI, 2016. Ikhtisar Hasil Pemeriksaan Semester (IHPS) 2 Tahun 2015.

Burrel, G., dan Morgan, G. 2005. Sociological Paradigms and Organisational Analysis: Elements of The Sociology of Corporate Life. Hampshire: Ashgate Publishing Limited.detik.com, 2015. Ini Mungkin Bukti Ahok, Predikat WTP dari BPK Tak Jamin Bebas Korupsi. Tersedia di : http://news.detik.com/berita/2962959/inimungkinbuktiahokpredi katwtpdaribpktakjaminbebaskorupsi.

Carcello, J. V., Hermanson, R.H. \& McGrath, N.T., 1992. Audit Quality Attributes: The Perceptions of Audit Partners, Preparers, and Financial Statement Users. Auditing: A Journal of Practice and Theory, 11 (January).

Chua, W. F. 1986. Radical Development in Accounting Thought. The Accounting Review, Vol. 61, No. 4, $601-632$.

DeAngelo, L.E., 1981. Auditor Size and Audit Quality. Journal of Accounting and Economics, 3(3), pp.183-199.

Deis, D.R. \& Giroux, G.A., 1992. Determinants of Audit Quality in the Public Sector. The Accounting Review, 67(3), pp.462-479.

Fadzly, M.N. \& Ahmad, Z., 2004. Audit Expectation Gap: The Case of Malaysia. Managerial Auditing Journal, 19(7), pp.897-915.

Francis, J.R., 2004. What Do We Know About Audit Quality? British Accounting Review, 36(4), pp.345-368.

Gadamer, Hans-Georg, 2010. Kebenaran dan Metode (Judul Asli: Truth and Method). Diterjemahkan oleh: Ahmad Sahidah. Yogyakarta. Pustaka Pelajar.

Lin, Z.J. \& Chen, F., 2004. An Empirical Study of Audit "Expectation Gap" in The People's Republic of China. International Journal of Auditing, 115, pp.93-115.

Mak, T. dkk., 2005. Audit, Accountability and an aAuditor's Ethical Dilemma: A Case Study of HIH Insurance. Asian Review of Accounting, 13(2), pp.18-35.

Manullang, A., 2010. Pengaruh Tekanan Anggaran Waktu dan Risiko Kesalahan Terhadap Penurunan Kualitas Audit. Fokus Ekonomi, 5(1), pp.81 - 94.

Mardisar, D. \& Sari, R. N., 2007. Pengaruh Akuntabilitas dan Pengetahuan Terhadap Kualitas Hasil Kerja Auditor. Simposium nasional akuntansi X.

Martens, S.C. \& McEnroe, J.E., 1992. Substance over form in auditing and the auditor's position of public trust. Critical Perspectives on Accounting, 3(4), pp.389-401.

Martinis, M.R. De \& Burrowes, A.W., 1996. Materiality and Risk Judgements: A Review of Users' Expectations. Managerial Finance, 22(9), pp.16-34. 
Mohamed, D.M. \& Habib, M.H., 2013. Auditor independence, audit quality and the mandatory auditor rotation in Egypt. Emerald Insight, 6(2), pp.116-144.

Moleong, Lexy J. 2014. Metodologi Penelitian Kualitatif (Edisi Revisi). Bandung: PT Remaja Rosdakarya.

okezone.com, 2016. BPK: Opini Wajar Tanpa Pengecualian Bukan Berarti Bebas Korupsi. okezone.com. Tersedia di: http://news.okezone.com/read/2016/08/11/340/1461439/bpk? opini?wajar?tanpa?pengecualian?bukan?berarti?bebas?korupsi.Diakses pada 13 Agustus 2016).

Omoteso, K. \& Obalola, M., 2014. The Role of Auditing in the Management of Corporate Fraud. Ethics, Governance and Corporate Crime: Challenges and Consequences, (October), pp.129 -151 .

Pearson, M.A., 1987. Auditor Independence Deficiencies \& Alleged Audit Failures. Journal of Business Ethics, 6(4), pp.281-287.

Peraturan Badan Pemeriksa Keuangan Republik Indonesia Nomor 01 Tahun 2007 tentang Standar Pemeriksaan Keuangan Negara

Poespoprodjo, W., 1987. Interpretasi. Bandung. Remadja Karya.

Porter, B., 1993. An Empirical Study of the Audit Expectation-Performance Gap. Accounting and Business Research, 24(93), pp.49-68.

Rahardjo, M., 2010. Hermeneutika Gadamerian: Kuasa Bahasa dalam Wacana Politik Gus Dur. Malang. UIN-MALIKI Press.

Riahi-Belkaoui, Ahmed. 2007. Teori Akuntansi (Edisi 5 - Buku 2). Jakarta: Salemba Empat.

Setyaningrum, D., 2012. Analisis faktor-faktor yang mempengaruhi kualitas audit BPK RI. Jurnal akuntansi, 1, pp.1-24.

Steckel, R., Manry, D. \& Tritschler, J., 2014. Audit Quality: Association between Published Reporting Errors and Audit Firm Characteristics. Springer Gabler.

Sukriyah, I., Akram \& Inapty, B.A., 2009. Pengaruh Pengalaman Kerja, Independensi, Obyektifitas, Integritas dan Kompetensi Terhadap Kualitas Hasil Pemeriksaan Oleh: Simposium Nasional Akuntansi XII, pp.1-38.

Sumaryono, E., 1999. Hermeneutik: Sebuah Metode Filsafat. Yogyakarta. Kanisius.

tempo.co, 2014. Korupsi Al-Qur'an, Jauhari divonis 8 tahun penjara. Tersedia di: https://nasional.tempo.co/read/news/2014/04/10/063569710/korupsi-al-quran-jauharidivonis-8-tahun-penjara.

tempo.co, 2015. Korupsi Haji, Suryadharma Didakwa Rugikan Negara Rp27M. Tersedia di: https://nasional.tempo.co/read/newas/2015/08/31/063696598/korupsi-haji-suryadharma-dida kwa-rugikan-negara-rp-27-m.

Transparency International Indonesia, 2016. Corruption Perception Index 2015. Tersedia: http://www.ti.or.id/index.php/publication/2016/01/27/corruption-perceptions-index-2015.

Tuanakotta, Theodorus M., 2011. Berpikir Kritis dalam Auditing. Jakarta. Salemba Empat.

Tuanakotta, Theodorus M., 2015. Audit Kontemporer. Jakarta. Salemba Empat.

Undang-Undang Nomor 31 Tahun 1999 tentang Pemeberantasan Tindak Pidana Korupsi.

Undang-Undang Nomor 15 Tahun 2006 tentang Badan Pemeriksa Keuangan.

Watkins, A.L., Hillison, W. \& Morecroft, S.E., 2004. Audit Quality: a Synthesis of Theory and Empirical Evidence. Journal of Accounting Literature, 23, p.153.

Yin, R. K., 2015. Studi Kasus: Desain dan Metode. Depok. Rajagrafindo Persada.

Yuliati, R., Winarna, J. \& Setiawan, D., 2007. Expectation Gap antara Pemakai Laporan Keuangan Pemerintah dan Auditor Pemerintah. Simposium Nasional Akuntansi IX, pp.1 - 25. 